\title{
Application of E-Learning in Instructional Design Course
}

\author{
Sahat Siagian ${ }^{1 *}$, Pardomuan Naulli Josip Mario Sinambela ${ }^{2}$, Yasaratodo Wau ${ }^{3}$ \\ 1. Education Technology Program, Postgraduate Studies Faculty, Universitas Negeri Medan \\ 2. Mathematics Program, Faculty of Mathematics and Natural Sciences, Universitas Negeri Medan \\ 3. Out of School Education Program, Faculty of Educational Studies, Universitas Negeri Medan
}

Funded by: Directorate of Research and Community Service Directorate General of Strengthening Research and Development of the Ministry of Research, Technology and Higher Education in accordance with Research Contract Number: 027 / UN33.8 / LL / 2018

\begin{abstract}
This research aims to develop an e-learning based interactive learning model assisted by Edmodo for the Instructional Design course, this research is expected to produce (1) an e-learning based interactive learning model assisted by Edmodo that may be used properly, easy to learn and can be used for individual learning and learning material that refers to competencies that have been established, (2) To know the results of the implementation of the e-learning based interactive learning model assisted by Edmodo in the Instructional Design course as well as the right strategies used in Instructional Design course, (3) To determine the effectiveness of the e-learning based interactive learning model assisted by Edmodo in the Instructional Design course and to determine the model of interactive learning that is effective and efficient. This research was conducted three stages. In the first stage in the first year to do an analysis of the interactive learning model that is most appropriate to use in learning instructional design, through a survey of preliminary studies, including the identification of learning needs and determine the competency standards subjects, analysis of learning. Identified characteristic and early behavior of students, basic competence and indicator writing, writing reference benchmark tests, preparing instructional strategies, develop learning materials. Then proceed with the initial design manufacture moodel based learning, instructional design based e-learning, and develop story board.
\end{abstract}

Keyword: e-Learning, instructional design

DOI: $10.7176 / \mathrm{JEP} / 10-2-20$

\section{Introduction}

E-learning is a highly developed nowadays. Inline with constructivist's view, which defines learning as a constructive process where information is transformed into knowledge through the process of interpretation, correspondence, representation, and elaboration, the information and telecommunication technology rapid development offers so many new conveniences in learning that allow a shift in learning orientation from outsideguided to self-guided and from knowledge as possession become knowledge as construction.

The success of improving the quality of human resources through education is related to various aspects, one of which is the ability of lecturers to design a learning process. In this regard, Rooijakkers (1993) states that teaching is an attempt to transmit knowledge to others. Furthermore, Gagne,Briggs \& Wager (1992) say that learning is an activity that can make learners learn and easily know what is conveyed. In order to achieve this, of course, leraning can not be separated from the learning media that is used as a tool to deliver messages. Therefore, what concern a lecturer is how a lecturer is able to choose and use the media and to adapt it to the material, nature and characteristics of the science and students characteristics so that the lecture contents become interesting and easily understood by students.

The development of science and technology has led to changes in learning materials. There are two types of learning material, which are called printed teaching materials and non-printed teaching materials. Non-printed teaching materials are teaching materials that are developed to enrich students' understanding of the subject matter learned, in addition to filling in the shortcomings that arise due to the problem of reading habits also in time constraints and to answer the diversity of students learning styles. The development of non-printed teaching materials must be able to make the most of the media's capabilities. In other words, the selection of suitable media in accordance with the specified teaching material is an important first step, using simple language, communicative and clear, capable of engaging students in thinking processes and allowing students to achieve a level of mastery independently. 
Education that gets a touch of information technology media has sparked the birth of the idea of e-learning or electronic learning. There are various types of e-learning platform which are currently used widely, such as Moodle, Blackboard, Sakai, Dokeas and edmodo. The e-learning uses electronic circuits or internet networks to convey the content of learning, interaction or guidance Rusman (2009). In addition e-learning as a form of distance education is done through internet media. E-learning is also an indirect (asyinchronous) learning activity through electronic devices to obtain learning material that suits the needs. Thorne Koye (2003) The potential of e-Learning as a part of blanded learning is almost limiting and represente a naturaly evolving process from traditional forms of learning to a personalited and focus development path.

The Educational Technology Study Program is one of the study programs in Universitas Negeri Medan's (Unimed's) Postgraduate Program. One of the Educational Technology areas is the utilization area, so that the use of information technology in learning activities may improve the quality of learning and by itself student learning outcomes will increase. Pratama (2014) that some of the problems that occur in learning in the world of education are (1) most of the learning concepts that are carried out are abstract, (2) limited time available to teach the content to be delivered and (3) lack of learners' participation in the learning process. Smaldino (2008) Technology, especially in digital formats, permeates our work and play. Technology and media have transformed not only the world of work and leisure but the world of education as well. also found that these problems can be overcome by using more concrete models of teaching materials delivered by teachers in the form of images, animations or videos and by applying learning approaches that involve students, which can be done by utilizing the internet as a communication tool in order to maximize the participation of students so that the limitations of time constraints can be overcome, and also by providing teaching materials that can be learned individually by students outside the classroom. One such learning innovation existing is by integrating the instructional design learning process with Information and Communication Technology which is better known as e-learning based interactive learning.

One of e-learning interactive learning models that most widely used on instructional design learning is Edmodoassisted interactive learning model. Edmodo is a site used by teachers/lecturers, and students/parents to facilitate the online learning process. The main goal of using EDMODO is helping to connect teachers and students in each school and also to ensure that they are connected throughout the world. Edmodo offers a safer and easier class to connect with one another, by offering a real time-based platform for exchanging ideas, content, and accessing homework, marks, and important information from school. This interactive learning model helps in planning, analyzing, implementing, and managing learning. It also provides access to learners for the learning material whenever and wherever students are. In Postgraduates Program of Universitas Negeri Medan all these features are discussed in the Instructional Design course. The aim of this course is for students to conduct instructional needs analysis and to determine instructional objectives, to conduct instructional analysis, to identify students' initial abilities and characteristics, to make a criterion reference tests, to develop instructional strategies, to select and develop instructional materials, to conduct formative evaluations, and to do summative and other evaluations.

The student-centred view in learning process raises a new assesment concept is centered on learners called learner-centered assessment. The definition of learner-centered assessment is parallel to the traditional definition of criterion reference test, as a core element of learning that is systematically designed. This type of test is important for evaluating student development and the quality of learning. Almost all instructional design models put the main emphasis on formative evaluation. The data collected and summarized through this evaluation provides information necessary for learning material to be revised in order to have a more precise learning material. There are two basic types of revisions that can be used. The first is the changes related to the content or substance of learning material so the learning tool may become more accurate or more effective. The second is the changes related to the procedure used in using the materials.

Formative assessment is carried out as a constructive process. However, at some point, it is important to know whether our teaching has been effective. In order for us to reach that decision, summative assessment needs to be carried out. Sumative evaluation is the process of collecting data and information in order to make decisions about the acquisition of learning objectives that have been designed. There are two stages of summative evaluation. The first focuses on the relationship between instructional, interests, and organizational needs. The second stage is an instructional field trial. 
AECT (1977) defines the model as conceptualization in the form of equations, physical equipment, descriptions, or graphical analogies that describe the actual situation or situation. The model, though it does not describe something exactly as the actual reality, but is seen as an "original replica". The clearer the replica is, the better it is as a model. Refer to the learning model as an "Instructional Model" and define it as "an integrated set of component strategies such as: the particular way the content ideas are sequenced, the use of overview and summaries, the use of examples, the use of practice, and the use of different strategies for motivating the student". This opinion emphasizes the notion of learning models as a number of strategic components that are arranged integratively, consisting of systematic steps, application of ideas, examples, exercises, and various strategies to motivate learners. Thus the term learning model will not be separated from patterns, examples or references that can be used as guidelines in the implementation of learning.

The learning model is a series of components of an integrated learning strategy, including: (1) syntax and sequence of ideas of the content, (2) usage of examples, (3) use of practices, and (4) the use of different strategies to motivate student to be engaged in learning. The model can be in the form of objects or can also be a procedure or a description of systematic steps of a process Dick and Carey (2005). The learning model is basically a form of a learning that is drawn from the beginning to the end which is presented specifically by teacher. The learning model consists of syntax, social systems, principles of reaction and support systems.

The development of interactive learning models in the Instructional Design course emphasizes learning design as a guide in the implementation of learning in order to achieve an effective, efficient, attractive and humanistic learning. In this study the development of interactive learning models used Gall, Borg \& Joyce (2003), and combined with to develop related learning plans. Borg and Gall development models contain systematic guidelines for the steps conducted by researchers so that the product they have designed has a feasibility standard.

States that the procedure of developmental research basically has two main objectives: (a) developing a product, and (b) assessing the product effectiveness as a validation in achieving the goal. Thus, research concepts are more precisely interpreted as development efforts that are also complimented with the validation efforts. There are 10 general steps that must be taken out in this context as described in the following figure.

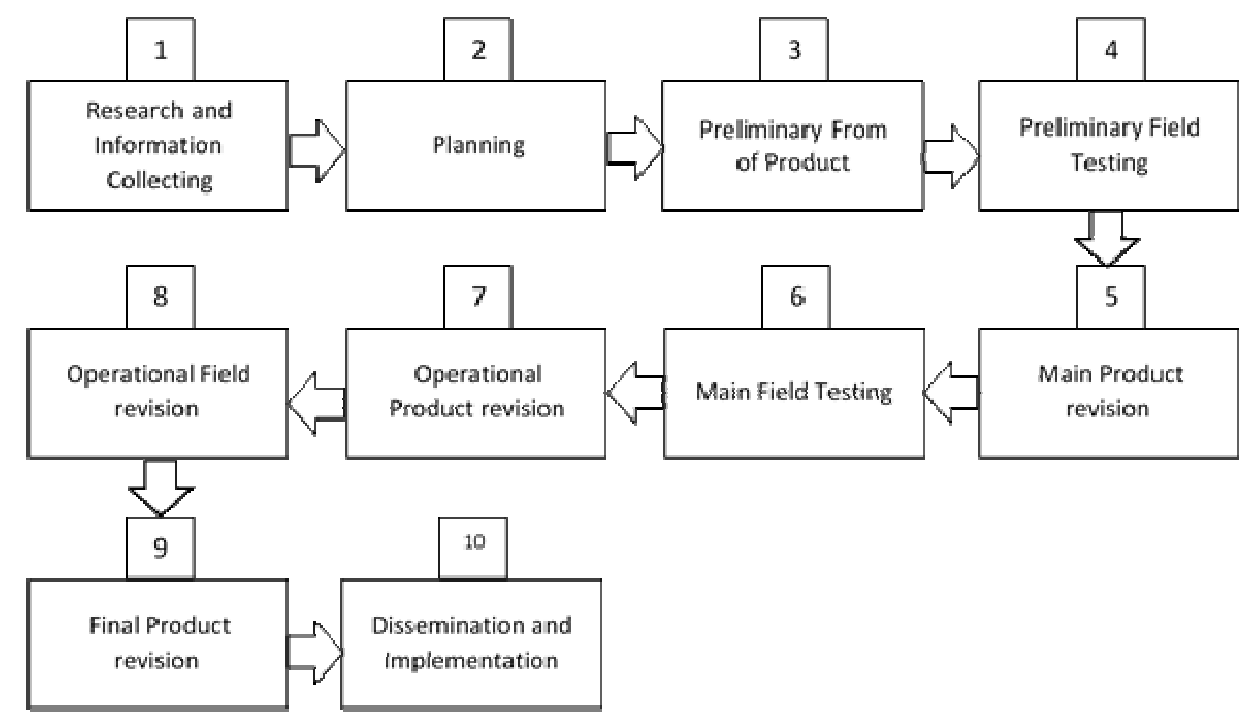

Figure 1: Borg \& Gall developmental procedure (2003)

1) Research and information collecting; literature study related to problems

2) Planning; formulating the skills and competence related to the problem

3) Develop preliminary form of product; develop the initial form of the product that will be produced

4) Preliminary field testing; conduct initial field trials in a limited scale of observation or questionnaire.

5) Main product revision; improving the initial product based on the results of the initial trial.

6) Main field testing; the main trial that involves all students. 
7) Operational product revision; improving the main product based on the results of main field testing.

8) Operational field testing; validation test of the operational model that has been produced so far.

9) Final product revision; making final improvements to the developed model.

10) Dissemination and implementation; disseminating and implementing the final product.

Knapp and Glenn (1996) suggests that students prefer to use of technology (computers) and to attend a computer-based learning. Effective computer software programs actively engage students and allow the students to control it freely. By combining computer technology into learning, it can also improve students' positive attitude towards campus, courses and learning in general.

As an interactive learning model development plan, this research was conducted in three phases: (1) Early development phase: analyzing instructional needs and determining instructional objectives, conducting instructional analysis, identifying initial abilities and characteristics of students, (2) Developmental phase: developing a criterion referenced test, developing instructional strategies, choosing and developing instructional materials, planning learning materials, (3) evaluating and revising the formative and summative evaluations.

Based on these phases, this research begins with preliminary research, which includes: identifying the learning needs and determining competency standards for the course; analyzing learning; identify the characteristics and initial behavior of students; determining standard competencies and their indicators; creating criterion reference test, developing learning strategies; developing learning materials. Then continued with the second phase that includes: initial design of interactive learning models based on chosen e-Learning platform (in this case Edmodo); developing learning designs that match the model; making model storyboard. After that the next phase covered carrying out the evaluation of the model, including: evaluation by experts, product review and trial, making a manual for using the learning model and testing the effectiveness and efficiency of the model.

This study involved students as participants and also six students as the members of researchers team, which are two students from Doctorate Program and four students from Master program of Education Technology Study Program in Postgraduste Program of Universitas Negeri Medan (Unimed). This research deals with the development of interactive learning models and was supported by the facility provided by Postgraduste Program of Unimed. This research also inline with the vision and mission of Unimed which is improving the quality of graduates through research on innovative learning resources. This research also inline with the Strategic Plan of Unimed for 2016-2020 which refers to the fulfillment four pillars of National Education Standards the: 1) Teaching Learning Quality, 2) Research and Community Development Quality, 3) Graduate Employability, 4) International Recognition. From reasearh aspect this strategic plan may be achieved by taking into account the various internal and external dynamics of the university, so that it can be used as a reference in the development of research in Unimed.

Various program achievement indicators also illustrate the efforts that must be done so that university vision as a university that excels in education, industrial engineering and culture can be fulfilled. Considering all matters described before especially the technology that developed very fast and the intention to support Unimed policy to fulfill the four pillars of national standard education, this research about the development of interactive eLearning based learning model is feasible. The results of this study can contribute to the institution through innovative learning innovations by utilizing the existing facilities in Unimed, namely internet facilities such as Wifi in the Postgraduate Pogram of Unimed and this facility is free to be used by all students. The results of research in phase I produced an e-learning based interactive learning model. In addition, this study has also produced a learning module that will be used as a guide in the implementation of interactive learning based on elearning. The application of interactive learning model based on e-learning that is the most and suitable for use in the Instructional Design course is Edmodo-assisted e-learning based interactive learning model. Edmodo is a site used by teachers/lecturers and students/parents to facilitate the online learning process. Edmodo spurs a safer and easier class to connect with one another, offers a real time-based platform to exchange ideas, content, and access homework, marks, and important information from school. This interactive learning model helps to plan, analyze, implement, manage learning and provide access to learners of the material whenever and wherever students are.

This developmental research aims to:

1. Develop an e-learning - based interactive learning models that are feasible to use, easy to learn and can be used for individual learning. 
2. To find out the results of the implementation of e-learning-based interactive learning model in the Instructional Design course.

3. To determine the effectiveness of e-learning based interactive learning models developed in the learning design subject.

Based on the problems that exist in the Instrucsonal Design course and the rapid development of technology, the development of interactive learning models based on e-learning is very important, because the presentation that will be delivered can vary including text, audio and images in accordance with the characteristics of the subject and the characteristics of students. Hence, the existence of this interactive learning model based on e-learning is inline Sadiman (2003) learning outcomes through vision around 75\%, through the hearing senses around $13 \%$, and through other senses around $12 \%$. Besides that, interactive learning media is also flexible in adjusting to one's learning speed. A student who has a higher learning speed can complete his/her learning activities faster, while students with slow learning speed can complete their learning activities according to their respective speeds.

This research supports the vision, mission, and goals Of Unimed, "to be a university that excels in the fields of education, industrial engineering and culture". Education research policies based on real needs in schools are carried out to enrich teaching materials in the field of education in the form of learning innovation innovations. The development of learning resources and an effective and efficient education system will be pursued by involving the academic community in collaboration with other relevant institutions. Based on the reasons above, this research is feasible, besides being able to produce learning innovations, this research also contributes unimed and also supports the vision and mission of Unimed..

\section{Research Methods}

The research method used is the developmental research model. The developmental model model which is combined with the developmental model.

This research was conducted in three stages. In the first stage an analysis of interactive learning models is most appropriate to be used in instructional design learning, through surveys in preliminary studies. The results of the first phase has produced model and interactive learning module based on e-learning equipped with CD tutorial as a guide in the implementation of interactive learning based on e-learning. The application of interactive learning based on e-learning models used in instructional design learning is interactive learning model based on elearning assisted with Edmodo.

In the second stage was testing the results of the first research for small and large scale. The result of this test would be later used as materials for revising the initial product. The third stage is for developing a manual for using the interactive learning models, evaluation, dissemination and socialization that can be do as an experiment to see the effectiveness and efficiency of the interactive learning model that has been developed. The following figure shows the stages of this research.

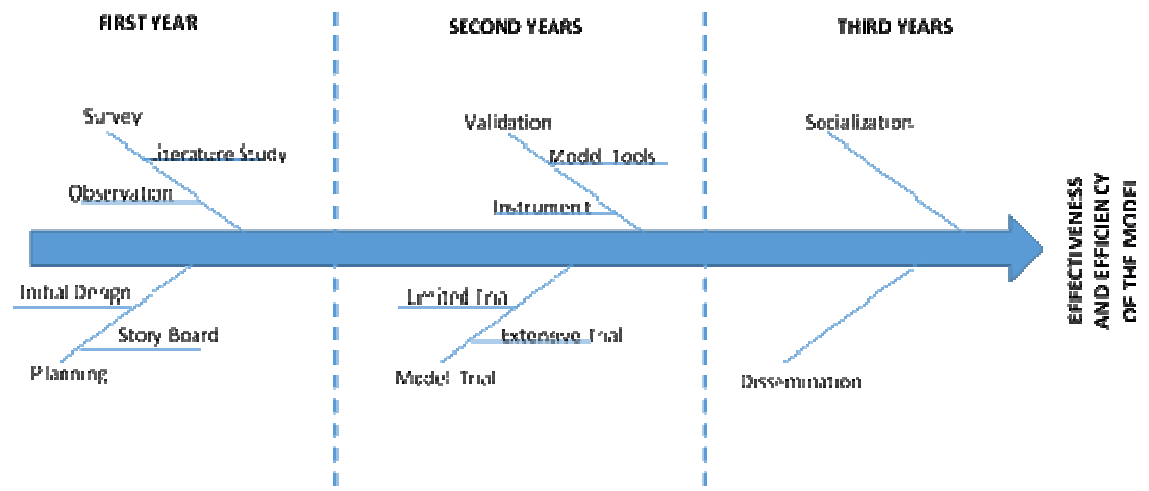

Figure 2. Research Stages 
This research was conducted for three years consisting of three stages. The first year which is the first category that develops an e-learning based learning model with the help of Edmodo. In the second year which is the second phase of this study validation has been carried out on the overall e-learning based learning model that has been obtained. The validation carried out is validation of the device model which includes teaching materials, lecture materials, items of question and all other instruments. Next, limited experiment has been done, namely individual experiment and experiment on a larger scale with Edmodo-assisted e-learning based learning models in the Instructional Design courses. In the third year which is the third stage is the implementation of the product model to see the effectiveness and efficiency of the product being developed.

\section{Results And Discussion}

The implementation phase is to determine the effectiveness and efficiency of the implementation of the development of the learning model that is carried out so that the treatment is carried out in classes in large groups. This study uses research and development approaches (research and development) by taking three stages, namely (1) preliminary study, (2) planning and preparation of learning models, and (3) field tests of developed learning models. Preliminary studies conducted to determine the development needs of Edmodoassisted e-learning based learning models have been conducted in the first year. Based on the results of the preliminary study, it was found that the lecturers who supervised and students who took the Instructional Design course feel that there is a need for e-learning based innovation.

The development of this Edmodo-based e-learning based learning model was collaborated with face-to-face online learning. The results developed at each stage are the Analysis Phase, Design Phase, Development Phase, Implementation Phase, Evaluation Phase. Based on the results of the implementation and implementation of interactive learning based on Edmodo-assisted e-learning, there are several general descriptions for developing interactive multimedia instructional design. The descriptions that can be obtained are as follows:

1. Interactive learning based on e-learning assisted by Edmodo that was be developed to raise instructional design materials based on Information and Communication Technology

2. Interactive learning based on edmodo-assisted e-learning that is developed is interactive to users who play it and pack it as attractive as possible.

3. Interactive learning based on e-learning assisted by Edmodo which was developed to adapt to the role involved.

4. Interactive learning based on e-learning assisted by Edmodo which was developed to present learning materials while still referring to the flow of lectures and the stages of the material presented.

5. Interactive learning based on edmodo-assisted e-learning that is developed is interactive by providing challenges in the form of tasks, questions, evaluation questions and the existence of certain rules to answer them.

6. Interactive learning based on e-learning assisted by Edmodo that was developed can foster student motivation to learn.

Based on the results of the implementation of the product, the interactions that occur with the learning participants and the lecturers who teach the learning are obtained. Through the product development it was obtained that there are several important menus in Edmodo-assisted e-learning based learning for the Instructional Design courses including: evaluation, presentation, discussion, lecture assignments, instructional materials, learning media, important links, learning tools, and check for plagiarism. The examples of the face view of learning based on e-learning assisted with Edmodo are showed as follow.

\subsection{Lecture Task Menu}

This menu is a collection of tasks that students must complete in accordance with the time displayed on this menu. Delays in collecting assignments online indicate that the related student cannot send it back, except with the permission of the lecturer. The following is a lecture menu display. 


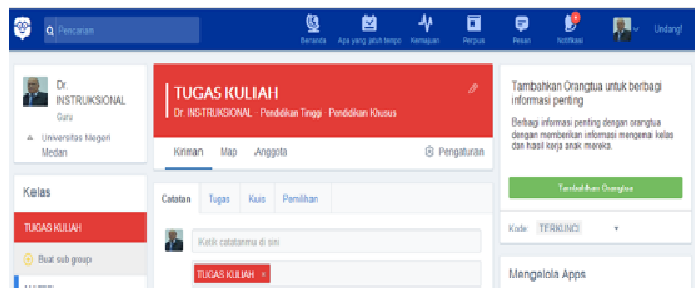

Figure 3a. Display Menu Techniques for e-learning

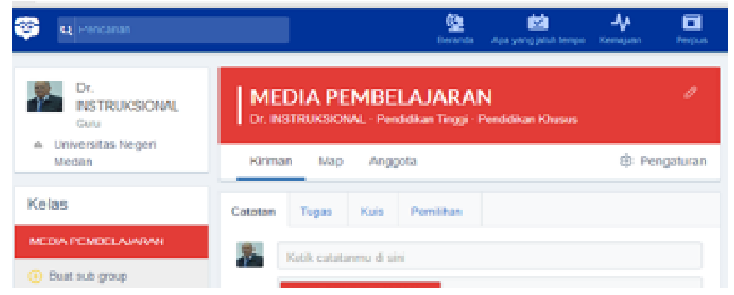

Figure 3b. Display Menu Techniques for e-learning

\subsection{Learning Media Menu}

This menu presents several ways related to learning media. The material can be in the form of power point, ms.word, ms.excel files, the images that are included are extension .jpg, .bmp, etc., as well as videos that contain .wmv, and other extensions. The following are the learning media menu.

\subsection{Plagiarism Check Menu}

On this lecture menu the participants of the lecture can detect the collected students who did the discussion or not. This is especially needed in the assessment. The lecturer must be able to provide a good assessment of the creativity of the student's work. The following is shown the check menu of plagiarism.

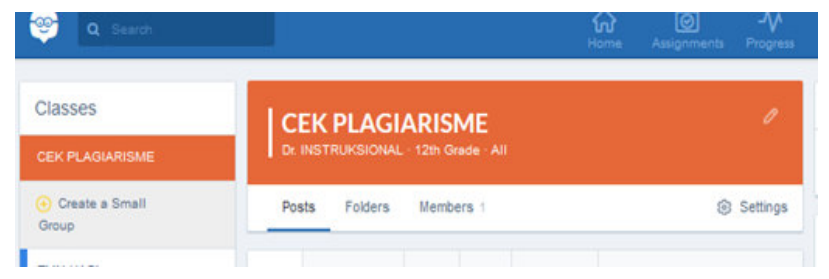

Figure 4. Check Plagiarism Menu

1.4. Students' learning achievement data

The results of students' learning are the results of the entire carried out assessment. Assessment of the tasks assigned, quizzes, and mid and final tests of the term. The results obtained are evaluated to take decisions on programs and models that have been developed. The results of Learning achievement are presented in Table 1

Tabel 1. Persentase Kelul;usan Mahasiswa Pascasarjana

\begin{tabular}{|l|l|l|l|l|}
\hline NO & Number of students & $\%$ & Score & Category \\
\hline 1 & 28 & 67 & A & Very Competent \\
\hline 2 & 10 & 24 & B & Competent \\
\hline 3 & 4 & 9 & C & Less Competent \\
\hline
\end{tabular}

Based on the table above, it can be clearly identified that the percentage of students who scored $\mathrm{A}=67 \%(28$ students), $\mathrm{B}=24 \%$ (10 students), and $\mathrm{C}=9 \%$ (4 students). This percentage shows that Instructional Design learning by using Edmodo successfully increases student learning achievement. Similarly, these results also indicate that the existing facilities in Edmodo can increase student interest and learning outcomes. 
Tabel 2. Student Attitude To Edmode Display Menu

\begin{tabular}{|c|c|c|c|c|c|c|c|}
\hline \multirow[b]{2}{*}{ No. } & \multirow[b]{2}{*}{ Display Menu } & \multicolumn{4}{|c|}{ Student Statement } & \multirow[b]{2}{*}{ Average } & \multirow[b]{2}{*}{ Category } \\
\hline & & $\begin{array}{l}\text { Very } \\
\text { good }\end{array}$ & Good & $\begin{array}{l}\text { Good } \\
\text { Enough }\end{array}$ & Not good & & \\
\hline 1 & Percentage & 34 & 7 & 1 & - & 3.8 & Very good \\
\hline 2 & Media & 34 & 6 & 1 & 1 & 3.7 & Very good \\
\hline 3 & Task & 32 & 8 & 1 & 1 & 3.7 & Very good \\
\hline 4 & Quiz & 33 & 7 & 2 & - & 3.8 & Very good \\
\hline 5 & Evaluation & 32 & 8 & & - & 3.7 & Very good \\
\hline
\end{tabular}

The student response towards the Edmodo display used in the instructional design learning shows that the percentage display menu is very good; with 34 students stated that it is very good, 7 students claimed it as good, while the remaining stated it is good enough. For the media display menu, 34 students claimed it as very good, 6 people claimed it as good, one person stated it good enough and one person said that it is not good. Further, the students in general claimed that the Task, Quiz, and Evaluation display menu are very good. Likewise, the average score of all display menu ranged between 3.7 and 3.8, which is categorized as very good.

Tabel 3. Lecture Attitude Toward Edmodo in Instruksioanal Design Laerning

\begin{tabular}{|l|l|l|l|l|l|l|l|}
\hline \multirow{2}{*}{ No. } & \multirow{2}{*}{ Display Menu } & \multicolumn{3}{|l|}{ Lecturer Statement } & \multirow{2}{*}{ Average } & Category \\
\cline { 3 - 8 } & & Very good & Good & Good Enough & Not good & & \\
\hline 1 & Percentage & 3 & - & - & - & 4 & Very good \\
\hline 2 & Media & 2 & 1 & & & 3,6 & Very good \\
\hline 3 & Task & 3 & - & - & & 4 & Very good \\
\hline 4 & Quiz & 2 & 1 & - & - & 3,6 & Very good \\
\hline 5 & Evaluation & 2 & 1 & - & - & 3,6 & Very good \\
\hline
\end{tabular}

The lecturer response towards the Edmodo display menu used in instructional design learning, as in the above table, shows that the average score obtained from the questionnaire run for all the display menu was 3, 6 and 4 . This result indicates that the lecturer attitude towards Edmodo display menu is very good. 
Tabel 4. Student Attitude Towards The Learning Implementation

\begin{tabular}{|c|c|c|c|c|c|c|c|}
\hline \multirow[b]{2}{*}{ No. } & \multirow[b]{2}{*}{ Display Name?? } & \multicolumn{4}{|c|}{ Student Statement } & \multirow[b]{2}{*}{ Average } & \multirow[b]{2}{*}{ Category } \\
\hline & & $\begin{array}{l}\text { Very } \\
\text { good }\end{array}$ & Good & $\begin{array}{l}\text { Good } \\
\text { Enough }\end{array}$ & Not good & & \\
\hline 1 & $\begin{array}{l}\text { E-Learning Learning } \\
\text { Implementation }\end{array}$ & 36 & 5 & 1 & - & 3.8 & Very good \\
\hline 2 & $\begin{array}{ll}\text { Edmodo } & \text { Facilities } \\
\text { Displayed } & \end{array}$ & 34 & 6 & 1 & 1 & 3.7 & Very good \\
\hline 3 & $\begin{array}{l}\text { Lecturer-Student Interaction } \\
\text { Pattern }\end{array}$ & 37 & 4 & 1 & - & 3,9 & Very good \\
\hline 4 & Time Spent & 35 & 7 & - & - & 3.8 & Very good \\
\hline 5 & $\begin{array}{l}\text { Learning Atmosphere / } \\
\text { Conditions }\end{array}$ & 36 & 7 & - & - & 3.9 & Very good \\
\hline
\end{tabular}

The above table shows that the student overall attitude towards the implementation of instructional design learning by using Edmodo - in terms of e-learning, Edmodo facilities, lecturer-student interaction pattern, time spent, learning atmosphere / conditions - is very good. This result indicates that instructional design learning using Edmodo attracts student attention and makes it easier for students to learn. In addition, students can use Edmodo as one of the independent learning facilities. As such, instructional design learning can overcome the learning problems of students who do not have time for face-to-face learning. Learning with Edmodo allows students to learn anytime and anywhere that it saves time and space. This model is, therefore, believed to be more effective than the learning model currently used.

\section{Conclusions}

Based on the stages of research and development that have been passed, conclusions in the report From the results of the research stages and the development that has been carried out, it can be concluded that:

1. The implemenytation of e-learning based interactive learning assisted by edmodo in the Instructional Design courses is effective and efficient.

2. Almost all students responded positively regarding learning using Interactive Learning Tools based on edmodo-assisted e-learning, in the context of being able to bring benefits, interesting, and can increase student learning motivation.

3. The use of e-learning based interactive learning assisted by edmodo can help to make it easy for students in learning the contents.

\section{Acknowledgements}

Thank you to the Directorate of Research and Community Service of the Directorate General of Research and Development Strengthening the Ministry of Research, Technology and Higher Education which has funded this research in accordance with the Research Contract Number: 027 / UN33.8 / LL / 2018, hopefully the results of this study are useful for progress education.

\section{Reference}

AECT. (1977). Definisi Teknologi Pendidikan (satuan tugas definisi \&terminologi AECT). Jakarta: Rajawali.

Dick, W. dan Carey, L. (2005). The Systematic Design of Instruction. United States of America: Scott Foresman and Company.

Gagné, R.M.;Briggs, L.J \& Wager, W.W. (1992). Principles of Instruction Design. New York: Saunders College Publishing

I.PA.E Pratama. (2014). Sistem Informasi dan Implementasinya, Jakarta: Informatika.

L.R Knapp, A.D Glenn. Restructuring Schools with Technology. (1996).

M. D. Gall, Walter R. Borg, Joyce P. Gall. (2003). Educational Research: An Introduction, 7th Edition. 
Rooijakkers, A. (1993). Mengajar Dengan Sukses: Petunjuk Untuk Merencanakan dan menyampaikan Pengajaran. Jakarta: Gramedia.

Rusman. (2009).Teknologi Informasi dan Komunikasi Dalam Pembelajaran. UPI Bandung.

Sadiman, A. dkk. (2003). Media Pendidikan, Pengertian, Pengembangan dan Pemanfaatannya . Jakarta : Pustekkom Dikbud.

Smaldino, E. S., dkk. (2008). Instrucional Technology and Media For Learning. New Jersey: Upper Saddle River

Thorne Kaye. (2003). Blended Learning: How to Integrate Online and Traditional Learning. Great Britain and United States in 2003 by Kogan page Limited. 